\title{
Effect of sugarcane silage on productive parameters of replacement Holstein-Friesian heifers
}

\author{
Efecto del ensilado de caña de azúcar en los parámetros \\ productivos de vaquillas Holstein-Friesian para reemplazo
}

\author{
José Reyes G, ${ }^{1}$ Ph.D, Oziel Montañez-Valdez, ${ }^{1 *}$ Ph.D, Candido Guerra M, ${ }^{2}$ Ph.D, \\ José Palma G, ${ }^{3}$ Ph.D.
}

\begin{abstract}
${ }^{1}$ University of Guadalajara, Centro Universitario del Sur, Departamento de Desarrollo Regional. Ave. Enrique Arreola Silva 883, Ciudad Guzman, Jalisco. 49000. Mexico. ${ }^{2}$ University of Guadalajara, Centro Universitario de la Costa Sur, Autlan de Navarro, Jalisco. Departamento de Desarrollo Regional ${ }^{3}$ Universidad de Colima, Centro Universitario de Investigacion y Desarrollo Agropecuario. Carretera Colima-Manzanillo. Km 40. Colima, Mexico. ${ }^{*}$ Correspondence: montanez77@hotmail.com
\end{abstract}

Received: June 2013; Accepted: October 2013.

\begin{abstract}
Objective. Measure the productive parameters of Holstein-Friesian females from weaning to 470 days old, comparing feeding through sugarcane silage (SCS) and corn silage (CS) in a concentrated fodder ratio of 70:30. Materials and methods. Twenty-eight post-weaning calves were used, with an average age of $80 \pm 16$ days old and an initial weight of $79.5 \pm 12.9 \mathrm{~kg}$. The T-Student test was used for the comparison of means, where calves were divided into two groups of 14 , one for each treatment. The body weight BW $(\mathrm{kg})$, wither height WH $(\mathrm{cm})$, body condition BC (1 to 5 scale), daily weight gain DWG $(\mathrm{kg})$ and feed conversion FC $(\mathrm{kg})$ was measured every 30 days. Results. Differences were found between treatments, where heifers fed with SCS showed better BC (3.12), FC (7.4) as compared to the CS treatment. No significant differences were found in terms of DWG $(0.666$ and $0.743 \mathrm{~kg} / \mathrm{d})$. Conclusions. Feeding based on sugarcane silage allows for an improved body condition and feed conversion of animals having with this an acceptable and cost-effective production performance in the raising of dairy replacements.
\end{abstract}

Key words: Corn, feeding of animals, silage, replacement (Source: NAL Thesaurus).

\section{RESUMEN}

Objetivo. Medir los parámetros productivos de hembras Holstein-Friesian desde el destete hasta los 470 días de edad, comparando la alimentación con ensilado de caña de azúcar (ECA) y ensilado de maíz (EM) en una proporción forraje concentrado de 70:30. Materiales y métodos. Se utilizaron 28 becerras, con una edad promedio de $80 \pm 16$ días y un peso inicial de $79.5 \pm 12.9 \mathrm{~kg}$. Se utilizó la prueba de comparación de medias T-Student, donde se dividieron las becerras en dos grupos de 14, uno para cada tratamiento. Cada 30 días se midió el peso corporal, PC (kg); altura a la cruz, AC $(\mathrm{cm})$; condición corporal, CC (escala de 1 a 5); ganancia diaria de peso, GDP (kg); y conversión alimenticia, CA (kg). Resultados. Se encontraron diferencias entre los tratamientos, donde las vaquillas 
alimentadas con ECA mostraron mejor CC (3.12), CA (7.4) en comparación con el tratamiento EM. No se encontraron diferencias significativas en cuanto a la GDP (0.666 y $0.743 \mathrm{~kg} / \mathrm{d})$. Conclusiones. La alimentación basada en ensilaje de caña de azúcar permite una mejora en la condición corporal y en la conversión alimenticia de los animales teniendo con esto un comportamiento productivo aceptable y económicamente rentable en la crianza de reemplazos lecheros.

Palabras clave: Alimentación de animales, ensilado, maíz, reemplazo (Fuente: NAL Thesaurus).

\section{INTRODUCCIÓN}

La recría es un componente vital de las explotaciones lecheras modernas, al proporcionar un abasto consistente y económico de reemplazos de alta calidad al hato, este objetivo se logra con la implementación de sistemas de crianza eficientes tanto en nutrición como en sanidad, que garanticen este fin, adecuándolos a la región y explotación en particular (1). En este sentido, Schingoethe y García (2), señalan que uno de los principales factores que limita el desarrollo de la ganadería lechera es la crianza de vaquillas de reemplazo, por lo que es imprescindible buscar alternativas de solución y diseñar sistemas de producción acorde con la realidad socio-económica, que en el caso de la industria lechera resulten en una producción eficiente, atractiva y económicamente costeable para el productor, además de accesible a toda la población y que permita la cría económica de los reemplazos para la preservación de estos sistemas.

En la producción bovina los forrajes juegan un papel crítico, dado a que son la fuente más económica de nutrientes, entre estos, los ensilajes son reconocidos por su baja variación en calidad alimenticia $(3,4)$. Por tanto, el ensilado de cultivos forrajeros podría ser una opción que contribuya de manera importante para optimizar el funcionamiento de los sistemas de producción animal (reemplazos lecheros) en zonas tropicales y subtropicales. Aunque es necesaria una suplementación apropiada para mejorar la producción, preferentemente de consumo lento con aportes adecuados de nitrógeno, lípidos y minerales para corregir sus limitantes $(5,6)$.

La caña de azúcar es posiblemente el cultivo herbáceo de mayor rendimiento en biomasa por unidad de área y de tiempo. Supera a otras plantas de altos rendimientos como el maíz y el trigo. Su capacidad de mantener una alta digestibilidad con la madurez creciente, le proporciona una ventaja importante como alimento para los rumiantes, especialmente durante la época seca cuando la mayoría de otros forrajes son poco disponibles y de baja calidad $(6,7)$.

La falta de información referente al desarrollo de vaquillas Holstein-Friesian futuros reemplazo de

\section{INTRODUCTION}

Breeding is a vital component of modern dairy farms, as it provides a consistent and costeffective supply of high-quality replacements, this goal is achieved through the implementation of efficient breeding systems both in nutrition as in health to ensure this purpose, adapting the same to the particular region and exploitation (1). In this sense, Schingoethe and Garcia (2) point out that one of the main factors limiting the development of dairy farming is the raising of replacement heifers, so it is essential to seek alternative solutions and design production systems according to the socio-economic reality, which in the case of the milk industry result in efficient, attractive and economically affordable production for the producer, as well as being accessible for the entire population and allow the cost-effective breeding of replacements for the preservation of these systems.

In bovine production fodder plays a critical role, since it is the most economical source of nutrients, among these silages are renowned by their low variation in nutritional quality $(3,4)$. Therefore, the silage of fodder crops could be an option that contributes significantly to optimize the operation of animal production systems (dairy replacements) in tropical and subtropical areas. Although appropriate supplements are required to improve production, preferably slow consumption with appropriate inputs of nitrogen, lipids and minerals to correct constraints $(5,6)$.

Sugarcane is possibly the herbaceous crop with the highest performance in terms of biomass per area and time unit. It outperforms other highyield plants such as corn and wheat. Its ability to maintain high digestibility with growing maturity provides an important advantage as food for ruminants, especially during the dry season when most other fodders are unavailable and of low quality $(6,7)$.

The lack of information concerning the development of Holstein-Friesian heifers that will be the future replacement of animals in production and their development with local 
animales en producción y su desarrollo con recursos forrajeros y alimentos locales, inducen a desarrollar éste tipo de trabajos por lo que el objetivo de este estudio fue evaluar el sistema de alimentación basados en ensilado de caña de azúcar en el desarrollo de becerras Holstein-Friesian.

\section{MATERIALES Y MÉTODOS}

Sitio de estudio. Este estudio se realizó en el Rancho Agropecuario "DOS PIVOTES" dedicado a la producción de leche y pie de cría (vaquillas para reemplazo y sementales), y producción de caña de azúcar para la industria. El rancho se ubica al suroeste del Municipio de Zapotlán El Grande, del Estado de Jalisco, México; con coordenadas geográficas de $19^{\circ} 27^{\prime} 13^{\prime \prime}$ de latitud norte y meridianos $103^{\circ} 27^{\prime} 57^{\prime \prime}$ de longitud oeste, con una altitud de $1.520 \mathrm{~m}$. El clima es semicálido, con una precipitación anual promedio de $732 \mathrm{~mm}$ distribuida en los meses de Junio a Septiembre, y lluvias invernales o cabañuelas de manera ocasional. Su temperatura media es de $20.2^{\circ} \mathrm{C}(8)$.

Procedimientos. Se utilizaron 28 becerras de la raza Holstein-Friesian con una edad inicial promedio de $80 \pm 16$ días y peso vivo en promedio de $79.5 \pm 12.9 \mathrm{~kg}$. Cada 30 días se midió el peso corporal, el pesaje de las vaquillas se llevó a cabo mediante la medición del perímetro torácico con cinta graduada en centímetros y empleo de la tabla de conversión para peso vivo, la altura a la cruz, con una regla vertical metálica de $1.5 \mathrm{~m}$ y una escuadra deslizable del mismo material, la condición corporal (CC) escala de 1 a 5, de acuerdo a Edmonson et al (9), la ganancia diaria de peso GDP (kg), consumo (g MS/kg PV ${ }^{0.75}$ )y conversión alimenticia (CA), durante un período de 470 días. Los animales fueron desparasitados con ivermectina. A los tres meses de edad se aplicó la bacterina Brucel ${ }^{R}$ RB51-PLUS contra brúcela y se reforzó la vacunación un mes después. Entre cuatro y cinco meses de edad se administró la vacuna contra complejo respiratorio (Express ${ }^{\mathrm{TM}} 10 \mathrm{HS}$ ), Pasterella (One-Shot $^{\mathrm{TM}}$ ) y Clostridium $\left(\right.$ Barvac $\left.^{\mathrm{TM}}\right)(10)$.

Las becerras fueron manejadas en dos lotes distribuidas al azar; en donde se propuso una relación de forraje:suplemento (70:30), base seca y se ofertó un consumo a razón del $3 \%$ de su peso corporal en materia seca. El tratamiento testigo fue el sistema de alimentación tradicional del Rancho con base en ensilado de maíz (Zea mays), rastrojo de maíz, heno de pasto Rhodes (Chloris gayana), concentrado comercial al $16.5 \%$ de proteína mediante una ración integral y el experimental con ensilado de caña de azúcar (Saccharum officinarumm) y un suplemento activador del rumen (SAR; Tabla 1) de forma separada del forraje. A los alimentos utilizados se les analizó su composición fodder and food leads to the development of this type of work, hence the objective of this study was to evaluate the feeding system based on sugarcane silage in the development of HolsteinFriesian heifers.

\section{MATERIALS AND METHODS}

Study site. This study was carried out in the Agricultural Farm "DOS PIVOTES" engaged in the production of milk and breeding stock (replacement heifers and stallions), and the production of sugarcane for the industry. The ranch is located to the southwest of the Municipality of Zapotlan El Grande, in the State of Jalisco, Mexico; with geographic coordinates $19^{\circ} 27^{\prime} 13^{\prime \prime}$ north latitude and meridians $103^{\circ} 27^{\prime} 57^{\prime \prime}$ west longitude, with an altitude of $1.520 \mathrm{~m}$. The climate is warm, with average annual rainfall of $732 \mathrm{~mm}$ distributed in the months of June to September, and occasional winter or summer rainfall. Its average temperature is $20.2^{\circ} \mathrm{C}(8)$.

Procedures. Twenty-eight Holstein-Friesian calves were used with an initial average age of $80 \pm 16$ days old and an average live weight of $79.5 \pm 12.9 \mathrm{~kg}$. The body weight was measured every 30 days, the weighing of the heifers was carried out through the measurement of the thoracic perimeter with a tape in centimeters and the use of a live weight conversion table, the wither height was measured with a metallic vertical ruler of $1.5 \mathrm{~m}$ and a sliding set-square of the same material, body condition (BC) with a 1 to 5 scale according to Edmonson et al (9), daily weight gain DWG $(\mathrm{kg})$, consumption ( $\mathrm{g}$ $\mathrm{MS} / \mathrm{kg} \mathrm{PV}^{0.75}$ ) and feed conversion (FC), during a period of 470 days. Animals were treated with ivermectin. At three months of age the bacterin

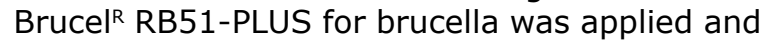
the vaccination was strengthened one month later. Between four and five months old, a vaccine for bovine respiratory disease complex was administered (Express $\left.{ }^{\mathrm{TM}} 10 \mathrm{HS}\right)$, Pasterella (OneShot $^{\mathrm{TM}}$ ) and Clostridium (Barvac $\left.{ }^{\mathrm{TM}}\right)(10)$.

Heifers were handled in two lots distributed randomly; where a fodder:supplement ratio of (70:30) was proposed, dry base and a consumption rate of $3 \%$ of their body weight in dry base was suggested. The control treatment was the traditional feeding system of the Ranch based on corn silage (Zea mays), corn stover, Rhodes grass hay (Chloris gayana), commercial concentrate with $16.5 \%$ protein through a full portion and the experimental system with sugarcane silage (Saccharum officinarumm) and a supplement for the activation of rumen (SAR; Table 1) separately from the fodder. The foods used were analyzed for their chemical 
Table 1. Percentage composition of the supplement for the activation of rumen.

\begin{tabular}{|c|c|}
\hline Ingredient & $\%$ \\
\hline Lime & 4.40 \\
\hline Cement & 1.10 \\
\hline Alfalfa meal & 14.90 \\
\hline Soy & 9.90 \\
\hline Ammonium sulfate & 0.40 \\
\hline Urea & 4.40 \\
\hline Cottonseed meal & 5.02 \\
\hline Cracked corn & 17.20 \\
\hline Molasses & 21.10 \\
\hline Fish meal & 4.10 \\
\hline Overweight fat ${ }^{\mathrm{a}}$ & 11.00 \\
\hline Trace minerals ${ }^{\mathrm{b}}$ & 4.40 \\
\hline Table salt & 1.70 \\
\hline EM (Mcal Kg MS ${ }^{-1}$ ) & 2.60 \\
\hline
\end{tabular}

química de acuerdo a la AOAC (Tabla 2)(10). Para el cálculo de la energía metabolizable se utilizó la fórmula:

1.81+0.064×\%Proteína Bruta=Mcal EM kg-1 MS (11).

Análisis estadístico. Los datos obtenidos fueron analizados por medio de una prueba de T Student (12).

\section{RESULTADOS}

Los resultados obtenidos se muestran en la tabla 3. Se observó un mayor consumo en la estrategia de ensilado de maíz; sin embargo, la relación en el consumo de forraje-concentrado para el sistema con base en ensilado de caña de azúcar se mantuvo homogénea hasta el final del experimento.

Los animales jóvenes tuvieron un menor consumo del forraje, el cual se incrementó en la medida que el animal creció. La conversión alimenticia fue mejor para la estrategia de ensilado de caña; la evolución del consumo expresada en materia seca se observó un consumo inicial similar para los dos sistemas, pero a partir de los 200 días de edad se registró un mejor consumo en materia seca total para el sistema con ensilado de maíz, aunque esto no se vio reflejado en una GDP significativamente mayor, teniendo así mejor conversión alimenticia él ECA; demostrando con ello que su utilización puede ser más ventajosa que el EM. Los resultados reproductivos muestran una variación en cuanto al comportamiento productivo en relación a la estrategia productiva empleada según la etapa de desarrollo del ganado.

En la primera etapa que llega a los 350 días de edad, tanto el peso $(p<0.035)$ como la condición corporal $(p<0.001)$, tuvieron diferencia significativa, en estas variables, el sistema con ensilado de maíz resultó con mayores valores. Para la segunda etapa que termina a los 470 días de edad, en la condición corporal $(p<0.01)$ se observó diferencia favorable
Table 2. Chemical composition of the ingredients used in diets for the development of replacement Holstein-Friesian heifers.

\begin{tabular}{crrrrrr}
\hline \multirow{2}{*}{ Component } & ECA $^{\mathbf{a}}$ & EM $^{\mathbf{b}}$ & $\mathbf{S A R}^{\mathbf{c}}$ & $\mathbf{C C}^{\mathbf{d}}$ & $\mathbf{R M}^{\mathbf{e}}$ & H. Rhodes \\
\cline { 2 - 7 } & \multicolumn{5}{c}{$\%$} \\
\hline MS & 28.37 & 28.00 & 90.00 & 88.00 & 94.00 & 92.50 \\
PC & 8.73 & 8.54 & 27.20 & 16.50 & 4.50 & 2.70 \\
NNP & 1.13 & 0.99 & 2.96 & 0.80 & --- & 6.09 \\
FDN & 61.63 & 67.25 & --- & -- & 76.00 & 82.39 \\
FDA & 47.25 & 43.17 & --- & --- & 51.02 & 57.32 \\
PH & 4.07 & 4.50 & --- & --- & --- & --- \\
EM $^{f}$ & 2.04 & 2.30 & 2.30 & 2.50 & 1.90 & 1.80 \\
\hline
\end{tabular}

a Sugarcane silage; ${ }^{\mathrm{b}} \mathrm{Corn}$ silage; ' Supplement for the activation of rumen;

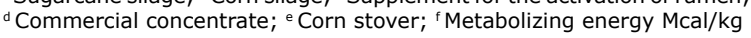

composition according to the AOAC (Table 2) (10). The following formula was used for the calculation of the metabolizing energy:

$1.81+0.064 \times \%$ Gross Protein $=$ Mcal EM kg-1 MS (11).

Statistical analysis. The obtained data were analyzed using the T Student test (12).

\section{RESULTS}

The results obtained are shown in table 3 . Higher consumption was observed with the corn silage strategy; however, the ratio in the consumption of fodder-concentrate for the system based on sugarcane silage remained homogenous until the end of the experiment.

Young animals had a lower consumption of fodder, which increased as the animal grew. The feed conversion was better for the sugarcane silage strategy; the evolution of consumption expressed in dry base was observed as a similar initial consumption for the two systems, but after 200 days of age better consumption was recorded in total dry base for the corn silage system, although this was not reflected in a significantly higher DWG, thus the SCS having better feed conversion; thereby demonstrating that its use may be more advantageous than CS. Reproductive results show a variation in terms of productive behavior in relation to the productive strategy employed according to the development stage of cattle.

In the first stage that ends at 350 days of age, both the weight $(p<0.035)$ and body condition $(p<0.001)$ had significant differences in these variables, the corn silage system resulted in higher values. For the second stage ending at 470 days of age, a favorable difference in the body condition $(p<0.01)$ was observed 
al sistema basado con ensilado de maíz, y en las demás variables no existió diferencia significativa.

Los resultados de consumo de $\mathrm{g} \mathrm{MS} / \mathrm{kg}$ de peso metabólico, conversión alimenticia e índice de consumo en las dos etapas, se anotan en la tabla 3, sin diferencia $(p>0.05)$ en la primera etapa para las tres variables. En la segunda etapa en las tres variables en estudio existió diferencia $(p<0.01)$, con mayores valores para el consumo tanto en $\mathrm{g} \mathrm{MS} / \mathrm{kg}$ PV ${ }^{0.75}$ e índice de consumo; sin embargo, la mejor conversión alimenticia se obtuvo con el sistema de ensilado de caña.

Con relación a las variables económicas, costo de alimentación/d y costo de alimentación/kg, fueron diferentes $(p<0.001)$, observando que el sistema con ensilado de caña de azúcar, mostró los menores costos de alimentación en las dos etapas evaluadas, teniendo con ello que el uso de ECA puede tener los mismos parámetros que con el uso de EM, pero económicamente resulta más rentable. in comparison to the corn silage system, and the other variables showed no significant difference.

The results of consumption of $\mathrm{g} \mathrm{MS} / \mathrm{kg}$ of metabolic weight, feed conversion and consumption rate in the two stages, are shown in table 3, with no difference $(p<0.05)$ in the first stage for the three variables. In the second stage there was a difference in the three variables under study $(p<0.01)$, with higher values for consumption both in $\mathrm{MS} / \mathrm{kg} \mathrm{PV}^{0.75}$ and consumption rate; however, the best feed conversion was obtained with the sugarcane silage system.

With regard to the economic variables, feeding cost/d and feeding cost/kg, these were different $(p<0.001)$, noting that the sugarcane silage system showed the lowest feeding costs in the two stages evaluated, having as result that the use of SCS may have the same parameters as the use of $\mathrm{CS}$, but it is more profitable economically.

Table 3. Average productive performance of different variables in Holstein-Friesian heifers in two feeding systems until puberty.

\begin{tabular}{|c|c|c|c|c|}
\hline & $\mathrm{ECA}^{\mathrm{a}}$ & $\mathrm{EM}^{\mathrm{b}}$ & EEM $^{c}$ & $\mathrm{Pd}^{\mathrm{d}}$ \\
\hline \multicolumn{5}{|c|}{ Weaning to puberty ( 80 to 350 days) } \\
\hline Initial weight (kg) & 78.8 & 80.2 & 4.885 & 0.774 \\
\hline Final weight $(\mathrm{kg})$ & $249.7 b$ & $287.1 \mathrm{a}$ & 16.786 & 0.350 \\
\hline Initial height $(\mathrm{cm})$ & 88.3 & 87.5 & 1.526 & 0.593 \\
\hline Height $(\mathrm{cm})$ & 117.3 & 120.8 & 1.871 & 0.078 \\
\hline Initial BC & 2.9 & 2.3 & 0.068 & 0.862 \\
\hline Final BC & $2.6 \mathrm{~b}$ & $3.4 a$ & 0.102 & 0.001 \\
\hline DWG (kg) & 0.6 & 0.8 & 0.097 & 0.244 \\
\hline Consumption g MS/kg PV 0.75 & 81.0 & 97.6 & 3.060 & 0.079 \\
\hline Feed conversion & 6.2 & 6.8 & 0.205 & 0.086 \\
\hline Feeding cost $/ \mathrm{d}^{*}$ & $0.63 b$ & $0.76 a$ & 0.217 & 0.001 \\
\hline Feeding cost/kg for weight gain* & 0.99 & 1.04 & 0.793 & 0.103 \\
\hline \multicolumn{5}{|c|}{ Puberty to service ( 351 to 470 days) } \\
\hline Initial weight $(\mathrm{kg})$ & $249.7 b$ & $287.1 \mathrm{a}$ & 16.786 & 0.035 \\
\hline Final weight $(\mathrm{kg})$ & 337.9 & 366.5 & 20.154 & 0.168 \\
\hline Initial height $(\mathrm{cm})$ & 117.3 & 120.8 & 1.871 & 0.078 \\
\hline Height $(\mathrm{cm})$ & 126.6 & 128.5 & 1.878 & 0.308 \\
\hline Initial BC & $2.6 \mathrm{~b}$ & $3.4 a$ & 0.102 & 0.001 \\
\hline Final BC & $3.1 \mathrm{~b}$ & $3.7 a$ & 0.086 & 0.001 \\
\hline DWG (kg) & 0.73 & 0.69 & 0.101 & 0.352 \\
\hline Consumption g MS/kg PV0.75 & $86.8 \mathrm{~b}$ & $108.7 a$ & 1.172 & 0.001 \\
\hline Feed conversion & $8.7 b$ & $12.9 a$ & 0.161 & 0.001 \\
\hline Feeding cost $/ \mathrm{d}^{*}$ & $0.79 b$ & $0.99 a$ & 0.151 & 0.001 \\
\hline Feeding cost/kg for weight gain* & $1.08 \mathrm{~b}$ & $1.43 a$ & 0.919 & 0.001 \\
\hline
\end{tabular}

a Sugarcane silage; ${ }^{\mathrm{b}}$ Corn silage; ${ }^{\mathrm{c}}$ Standard error of means; ${ }^{\mathrm{a}}$ Probability. $*$ Expressed in US dollars. 
Reyes - Effect of sugarcane silage on productive parameters

\section{DISCUSIÓN}

La utilización de ensilado de caña más un suplemento estratégico hace posible obtener un esquema económicamente competitivo en el desarrollo de becerras como futuros reemplazos en la ganadería lechera, comparado con la alimentación tradicional de ensilado de maíz. Aún al considerar que al final de la observación (470 días), el sistema basado en ensilado de maíz fue superior en AC y CC, estos resultados pueden ser atribuidos a la calidad de la ración base, pues el valor de energía calculado para el ensilado de caña resulto inferior al compararlo con ensilado de maíz y con un mayor contenido de la fracción fibra detergente ácido, que haría menos disponible la fibra consumida, además de un mayor consumo, pues fue superior en $1.6 \mathrm{~kg} \mathrm{MS} / \mathrm{d}$. Por otra parte, dada la perennidad y rendimiento de biomasa del cultivo de caña de azúcar permite incrementar el número de becerras a desarrollar con ensilado de caña.

En el aspecto productivo ambas estrategias con ensilado se ubican en las recomendaciones de diferentes autores de no sobrepasar ganancias de peso de entre 0.700 a $0.800 \mathrm{~kg} / \mathrm{d}$ en la etapa prepuber $(1,13)$. Con ello se descarta el efecto negativo que en animales prepúberes pueden tener con altos niveles nutricionales sobre el desarrollo de la glándula mamaria (engrasamiento) y consecuentemente sobre la producción láctea $(14,15)$. Sin embargo, con el ensilado de maíz la mejora en la condición corporal posiblemente se atribuya a un mayor engrasamiento, pues resultó en $27 \%$ superior al del sistema con ensilado de caña de azúcar y el tratamiento basado en ensilado de maíz fue superior a las recomendaciones de CC 2.4 a los siete meses de edad, de 2.8 a los $11 \mathrm{y}$ 3.0 a los 16 meses, comparada con $2.9,3.3$ y 3.6 para el sistema basado en EM, y de $2.6,2.6$ y 3.1 para ECA respectivamente. En este contexto, puede explicarse que la energía suministrada en exceso de los requerimientos impactó mayoritariamente la condición corporal $(16,17)$.

Osnaya (18), reporta al trabajar en el desarrollo de reemplazos para ganado Holstein con tres estrategias de alimentación: pastoreo, pastoreo más suplementación y sistema intensivo, las GDP fueron de $0.508,0.694$ y $0.560 \mathrm{~kg}$, respectivamente. En este sentido, cuando se compararon los resultados del sistema de ensilado de caña con trabajos de pasturas tropicales, resultaron con mayores ganancias a los indicados por Plaza et al (19), pues estos autores encontraron rangos de GDP de 0.496 a $0.563 \mathrm{~kg} / \mathrm{d}$ para la época de lluvias y de 0.395 a $0.455 \mathrm{~kg} / \mathrm{d}$ en la época seca, al utilizar pasto bermuda (Cynodon dactylon var. 68) con becerras Holstein de 90 días de edad y $88 \mathrm{~kg}$ de peso vivo de manera inicial. De forma parecida, el trabajo de

\section{DISCUSSION}

The use of sugarcane silage plus a strategic supplement makes it possible to obtain an economically competitive scheme in the development of heifers as future replacements in dairy farming, when compared to the traditional feeding with corn silage. Even considering that at the end of the observation period (470 days), the corn silage system was superior in $\mathrm{WH}$ and $\mathrm{BC}$, these results can be attributed to the quality of the base ration, since the energy value calculated for sugarcane silage was lower when compared with corn silage and with a higher content of the acid detergent fiber fraction, which would make the fiber consumed less available, in addition to increased consumption, as it was higher by $1.6 \mathrm{~kg}$ $\mathrm{MS} / \mathrm{d}$. On the other hand, given the durability and performance of the biomass of sugarcane crops it is possible to increase the number of heifers to be developed with sugarcane silage.

In the productive aspect, both silage strategies are within the recommendations of different authors of not exceeding weight gains from 0.700 to 0.800 $\mathrm{kg} / \mathrm{d}$ in the prepubertal stage $(1,13)$. This rules out the negative effect on prepubertal animals with high nutritional levels of the development of the mammary gland (greasing) and consequently on the milk production $(14,15)$. However, the improvement in the body condition with corn silage could be possibly attributed to a higher greasing, which resulted $27 \%$ higher than the sugarcane silage system and the corn silage treatment was superior to the recommendations of a BC of 2.4 at seven months of age, of 2.8 at 11 months and 3.0 at 16 months, compared to $2.9,3.3$ and 3.6 for the CS system, and 2.6, 2.6 and 3.1 for SCS respectively. In this context, it can be explained that the energy supplied in excess of the requirements mainly impacted the body condition $(16,17)$.

Osnaya (18), reports that when working on the development of replacements for Holstein cattle with three feeding strategies: grazing, grazing plus supplementation and intensive system, DWG were $0.508,0.694$ and $0.560 \mathrm{~kg}$, respectively. In this sense, when comparing the results of the sugarcane silage system with tropical pastures, these resulted in higher returns than those indicated by Plaza et al (19), as these authors found DWG ranges from 0.496 to $0.563 \mathrm{~kg} / \mathrm{d}$ for the rainy season and from 0.395 to $0.455 \mathrm{~kg} / \mathrm{d}$ during the dry season, when using bermuda grass (Cynodon dactylon var. 68) with Holstein heifers of 90 days of age and $88 \mathrm{~kg}$ of initial live weight. Similarly, 
Zamora et al (20), en pastoreo de estrella (Cynodon nlemfuensis) y suplementación obtuvieron GDP de $0.584 \mathrm{~kg} / \mathrm{d}$ en esta fase del desarrollo de becerras Holstein. Resultados superiores al de este trabajo encontraron Plazas y González (21) al comparar dos sistemas de crianza de becerras Holstein para reemplazo; estabulado y pastoreo desde el nacimiento hasta seis meses de edad, utilizando dos tratamientos de alimentación con base en pasto Kikuyo (Pennisetum clandestinim), ensilado de maíz y concentrado, y leche hasta los tres meses de edad, reportando valores de 1.004 y $0.974 \mathrm{~kg} / \mathrm{d}$.

En este contexto, resulta atractiva la posibilidad de implementar la alimentación con ensilado de la caña en animales en crecimiento, puesto que tendría un mayor impacto en el periodo de sequía. Asimismo, el consumo de MS, resultó similar al reportado para vaquillas Holstein para diferentes pesos corporales (22). Por lo cual, una posibilidad de incrementar el consumo con este tipo de estrategias es a través de mejorar las características forrajeras de la caña o incrementar el aporte del suplemento.

El sistema con ECA, mostró ser más económica en el $13 \%$, comparado con el sistema de EM, lo cual implica un ahorro en la alimentación y por consecuencia en la producción de vaquillas de remplazo, reduciendo los costos en $16.8 \%$ en la primera etapa (hasta antes del destete) y de hasta el $18 \%$ en la segunda etapa de este estudio, esto como resultado de emplear forrajes adaptados a las condiciones locales y con una alta productividad como es la caso del ensilado de caña de azúcar.

En conclusión el sistema con base en ensilado de maíz produce una mayor condición corporal, relacionada con el engrasamiento; afectando con ello la eficiencia reproductiva. Se generó una alternativa de desarrollo de becerras HolsteinFriesian al utilizar un sistema basado en ensilado de caña de azúcar y un suplemento de consumo lento para obtener hembras de reemplazo desde el destete hasta gestación para la industria lechera. the work of Zamora et al (20), in grazing (Cynodon nlemfuensis) and supplementation obtained a DWG of $0.584 \mathrm{~kg} / \mathrm{d}$ in this stage of the development of Holstein heifers. Plazas and González (21) found results superior to this work when comparing two breeding systems for replacement Holstein heifers; feedlot and grazing from birth to six months of age, using two feeding treatments based on Kikuyu grass (Pennisetum clandestinim), corn silage and concentrate, and milk until three months of age, reporting values of 1.004 and $0.974 \mathrm{~kg} / \mathrm{d}$.

In this context, the possibility of implementing sugarcane silage feeding in growing animals is attractive, since it would have a greater impact on the drought period. Likewise, the consumption of MS was similar to that reported for Holstein heifers with different body weights (22). Therefore, one possibility of increasing consumption with this type of strategy is through the improvement of the fodder characteristics of sugarcane or the increase of the contribution of the supplement.

The SCS system proved to be more economical in $13 \%$, as compared with the CS system, which means savings in feeding and therefore in the production of replacement heifers, reducing costs in $16.8 \%$ in the first stage (prior to weaning) and up to $18 \%$ in the second phase of this study, this is the result of the use of fodder crops adapted to local conditions and with high productivity as it is the case of sugarcane silage.

In conclusion the corn silage system produces a higher body condition, related to greasing, thereby affecting reproductive efficiency. An alternative for the development of HolsteinFriesian heifers was generated using a system based on sugarcane silage and slowconsumption supplement for replacement females from weaning until gestation for the dairy industry.

\section{REFERENCES}

1. Vetharaniam I, Davis SR, Upsdell M. Modeling the effect of energy status on mammary gland growth and lactation. J Dairy Sci 2003; 86:3148-3156.
2. Schingoethe DJ, García A. Alimentación y manejo de becerras y vaquillas lecheras. ExEx [en línea] 2004 [acceso 25 de julio de 2013]; ExEx4020S. URL disponible en: http:// pubstorage.sdstate.edu/AgBio_Publications/ articles/ExEx4020S.pdf. 
3. Silveira PE, Franco FR. Conservación de forrajes: Segunda parte. REDVET [en línea] 2006; [acceso 25 de julio de 2013]; 7(11). URL disponible en: http://www.veterinaria. org/revistas/redvet/n111106/110605.pdf

4. Santos MV, Gomez CA, Perea JP, García A, Guim A, Perez HM. Fatores que afetam o valor nutritivo da silagens de forrageiras tropicais. Arch Zootec 2010; 59:25-43.

5. Martín PC. La alimentación del ganado vacuno con caña de azúcar y sus subproductos. La Habana, Cuba: EDICA (Editorial del Instituto de Ciencia Animal); 2004.

6. Juárez LF, Vilaboa AJ, Díaz RP. La caña de azúcar (Saccharum officinarum): una alternativa para la sustitución de maíz (Zea mays) en la alimentación de bovinos de engorda. Sitio Argentino de Producción Animal [en línea] 2009 [acceso 25 de julio de 2013]; URL disponible en: http://www. produccion-animal.com.ar/informacion_ tecnica/invernada_o_engorde_a_corral_o_ feedlot/69-cana_azucar.pdf

7. Pardo NA. Manual de Nutrición Animal. Colombia: Editorial Grupo Latino; 2007.

8. Instituto Nacional de Estadística y Geografía (INEGI). Anuario estadístico del estado de Jalisco. México: [en línea] 2010. [fecha de acceso 20 de noviembre de 2013] URL disponible en: http://www3.inegi.org.mx/ sistemas/mexicocifras/default. aspx?e $=14$

9. Edmonson AJ, Lean IJ, Weaver LD, Farver T, Webster $\mathrm{G}$. A body condition scoring chart for Holstein dairy cows. J Dairy Sci 1989; 72:68-78.

10. AOAC. Official Methods of Analysis (18th) Association of Official Analytical Chemists. Arligton (VA), Washington DC: AOAC; 2006.

11. Martín PC, Palma JM. Manual para fincas y ranchos ganaderos. Colima, México: AgroSystems Editing; 1999.

12. SAS. User guide: statics. Versión 8.0 Edition. Cary (NC): SAS institute Inc; 2009.

13. Gabler MT, Heinrichs AJ. Dietary protein to metabolizable energy rations on feed efficiency and structural growth of prepubertal Holstein heifers. J Dairy Sci 2003; 86:268-274.
14. Daniels KM, McGillard ML, Boyle PL, Meyer MJ, Van Amburgh ME, Capuco AV, et al. Effect of increasing energy and protein intake on mammary development in heifer calves. J Dairy Sci 2005; 88:595-603.

15. Meyer MJ, Capuco AV, Ross DA, Lintault LM, Van Amburgh ME. Developmental and nutritional regulation of the prepubertal heifer mammary gland: I. Parenchyma and fat pad mass and composition. J Dairy Sci 2006; 89:4289-4297.

16. Pedroso AD, Nussio LG, Paziani SDF, Loures DRS, Igarasi MS, Coelho RM, et al. Fermentation and epiphytic microflora dynamics in sugar cane silage. Sci Agric 2005; 62:427-432.

17. Suksombat $\mathrm{W}$, Junpanichcharoen P. Feeding of sugar cane silage to dairy cattle during the dry season. Asian-Aust J Anim Sci 2005; 18:1125-1129.

18. Osnaya GF. Efecto del sistema de pastoreo rotacional en la crianza de vaquillas HolsteinFriesian sobre la eficiencia reproductiva. [Tesis Doctoral]. Colima, México: Universidad de Colima; 2000.

19. Plaza J, Martínez X, Ybalmea R, Enriquez V. Vermisol o la urea para el control parasitario de terneras en pastos tropicales. Rev Cub Cienc Agric 2000; 34:293-297.

20. Zamora A, Plaza J, Lara A. Nota acerca de un sistema de alimentación y manejo de novillas lecheras. Rev Cub Cienc Agríc 2000; 34:119-123.

21. Plazas R, y González M. Comparación de dos sistemas de cría de terneras Holstein, pastoreo y estabulación en la finca Villa María municipio Firavitoba - Boyacá. Conexión Agropecuaria 2012; 2:15-24.

22. NRC. Nutrient Requirements of Dairy Cattle. $7^{\text {th }}$ Revised Edition. Washington DC: National Academy Press; 2007. 